\title{
УДК 002:001.82
}

\section{Годз Оксана Володимирівна}

канд. філол. наук, науковий співробітник відділу наукової реферативної інформації Державна науково-педагогічна бібліотека імені В. О. Сухомлинського, м. Київ, Україна oksana_godz@i.ua

\section{АНАЛІЗ ВІДОБРАЖЕННЯ НАУКОВИХ ДОСЛІДЖЕНЬ З ПРОБЛЕМ ОСВІТИ І ВИХОВАННЯ В ПОЧАТКОВІЙ ШКОЛІ В ЗАГАЛЬНОДЕРЖАВНІЙ РЕФЕРАТИВНІЙ БАЗІ ДАНИХ «УКРАЇНІКА НАУКОВА»}

\begin{abstract}
Анотація. Розглянуто питання активізації формування реферативних ресурсів, зокрема 3 питань освіти й виховання в початковій школі. Подано результати аналізу реферування наукових праць 3 питань освіти й виховання в початковій школі у загальнодержавній реферативній базі даних «Україніка наукова». Означено тенденції розвитку початкової освіти і виховання в зазначеній базі даних. Виявлено реферативну інформацію щодо найактивніше досліджуваних тем у цій сфері й інтенсивність їх відображення. Висвітлено результати моніторингу серед авторефератів дисертацій та книжкових видань 3 питань освіти й виховання в початковій школі, проведеного на основі загальнодержавної реферативної бази даних «Україніка наукова».
\end{abstract}

Ключові слова: реферування; педагогіка; початкова освіта; загальнодержавна реферативна база даних «Україніка наукова»; український реферативний журнал «Джерело»; ДНПБ України ім. В. О. Сухомлинського.

\section{1. ВСТУП}

Постановка проблеми. Відповідно до Законів України «Про освіту» і «Про загальну середню освіту», початкова освіта є обов'язковою основною складовою безперервної освіти. Держава визнає пріоритетну роль початкової освіти і створює належні умови для їі здобуття. У наш час відбуваються динамічні зміни в суспільному й економічному житті країни, які не можуть не позначитися на освіті, у тому числі іiі початковій ланці як важливому чиннику виховання, навчання й розвитку дитини в новому тисячолітті. Результати цієї діяльності висвітлено у наукових працях вітчизняних педагогів. Серед інформаційних ресурсів, які допомагають ознайомитися 3 результатами наукової педагогічної діяльності, чільне місце посідає реферативна інформація, яка $є$ загальноприйнятою формою обміну науковими досягненнями $\mathrm{i}$ спілкування вчених у всьому світі, допомагає зорієнтуватися у потоці наукової літератури, одержати найновіші відомості щодо наукових досліджень у певних галузях знання.

Систему реферативних видань організовано так, що, навіть за умов значної диференціації галузей науки й великого обсягу літератури, у рамках єдиного видання охоплено всю галузь науки для того, щоб звільнити науковців від необхідності звертатися до реферативного журналу із суміжної спеціальності. Базою для його створення служить загальнодержавна реферативна база даних (БД) «Україніка наукова», започаткована у 1998 році, яка, за своєю суттю, $\epsilon$ національним інформаційним ресурсом, оскільки основним завданням ï створення, поповнення та функціонування $\epsilon$ досягнення стовідсоткового відображення друкованих наукових праць вчених нашої країни з усіх галузей знань. УРЖ «Джерело» увібрав усі види первинних документів: серіальні (періодичні і продовжувані), матеріали наукових конференцій, збірники наукових праць, наукові монографії, довідники й словники, 
офіційні і відомчі видання, документи державних і громадських організацій, посібники для вищих навчальних закладів, автореферати дисертацій [7, с. 58-62].

На сьогодні реферативна БД «Україніка наукова» i УРЖ «Джерело» $\epsilon$ невід'ємною складовою національного інформаційного ресурсу, який відображає ключові українські наукові публікації. Реферативна інформація стала інтегруючою основою української науки, адже свідоцтвом оприлюднення результатів наукових досліджень є їхнє відбиття в реферативних виданнях і базах даних [6, с. 140-144].

Аналіз останніх досліджень і публікацій. Питання сучасного стану і перспектив розвитку наукового реферування в Україні постійно перебуває в полі зору науковців, які досліджують проблеми формування і використання інформаційних ресурсів. Розвиток національної системи реферування розглядають у своїх публікаціях I. Балагура, В. Вергунов, С. Добровська, Н. Зайченко, С. Кириленко, Л. Костенко, А. Крючин, Н. Мініна, В. Петров, М. Сорока. Цьому питанню також присвячено низку публікацій наукових співробітників ДНПБ України ім. В. О. Сухомлинського, а саме: Т. Букшиної, I. Коваленко [3, с. 66-71; 4, с. 46-54; 5, с. 57-59], Т. Судіної [9, с. 56-59].

Не дивлячись на те, що ДНПБ України ім. В. О. Сухомлинського всього існує 13 років, розпочавши свою діяльність 3 «чистого аркуша», на сьогодні вона утвердилася як сучасний академічний науково-інформаційний центр НАПН України, координаційний науково-методичний центр педагогічних i навчально-педагогічних бібліотек освітянської мережі МОН України і НАПН України [1, с. 124-127].

Згідно 3 планом НДР ДНПБ України ім. В.О.Сухомлинського «Наукова організація інформаційної діяльності галузевого бібліотечного комплексу Державної науково-педагогічної бібліотеки України імені В. О. Сухомлинського (2012-2014)» у 2012 р. за напрямом «Визначення перспективних напрямів розвитку інформаційної діяльності галузевого бібліотечного комплексу ДНПБ України ім. В. О. Сухомлинського» здійснювалась робота щодо виявлення повноти опублікування реферативної інформації з питань педагогіки, психології та освіти, у тому числі і 3 питань освіти й виховання в початковій школі [2, с. 1].

Тому мета статті конкретизується системою виконання таких завдань, а саме:

- створення тематичного розподілу наукових досліджень 3 проблем освіти i виховання в початковій школі;

- простеження відображення дисертацій, книг та монографій з питань освіти й виховання в початковій школі в загальнодержавній реферативній базі даних «Україніка наукова»;

- проведення аналізу реферування наукових праць 3 питань освіти й виховання в початковій школі, розміщених у загальнодержавній реферативній базі даних «Україніка наукова»;

- дослідження активізації формування реферативних ресурсів з питань освіти й виховання в початковій школі.

Об'єкт дослідження - загальнодержавна реферативна база даних «Україніка наукова» та їі паперовому варіанті УРЖ «Джерело».

Предмет дослідження - автореферати дисертацій з проблем освіти й виховання в початковій школі за 1999-2012 роки, які розміщенні в загальнодержавній базі даних «Україніка наукова».

\section{2. РЕЗУЛЬТАТИ ДОСЛІДЖЕННЯ}

Розглянемо кількісні показники кумуляції реферативного ресурсу, динаміку реферування і тематику авторефератів і книжкових видань 3 питань освіти й виховання 
в початковій школі, представлених у загальнодержавній реферативній базі даних (БД) «Україніка наукова».

Загалом 3 обраної нами проблематики в загальнодержавній реферативній базі даних (БД) «Україніка наукова» представлено 1519 реферативних записів на наукові праці з питань освіти й виховання в початковій школі, 3 них:

- 222 рефератів дисертацій на здобуття вченого звання кандидата або доктора педагогічних наук (14,6 \% від загальної кількості);

- 925 рефератів книжкових видань (60,9 \% від загальної кількості);

- реферативна база 3 різних аспектів освіти й виховання в початковій школі представлена 351 рефератом (23,1 \% від загальної кількості);

- наукова періодика 3 питань початкової освіти представлена збірниками наукових праць Переяслав-Хмельницького державного педагогічного інституту ім. Григорія Сковороди «Школа першого ступеня: теорія і практика» i щомісячним науково-методичним журналом Міністерства освіти і науки України «Початкова школа» (0,1 \% від загальної кількості);

- що стосується журналів і продовжених видань, то їх налічується 19 (1,3\% від загальної кількості).

Аналіз представлених авторефератів дисертацій, які стосуються тематики, що аналізується, за період з 1999 по 2012 рік відносяться до спеціальностей 13.00.02 (Теорія і методика навчання), 13.00.01 (Загальна педагогіка та історія педагогіки), 13.00.09 (Теорія навчання), 13.00.07 (Теорія і методика виховання) дав можливість визначити статистичні дані для розгляду.

Розглянемо динаміку зростання захистів дисертацій за роками (табл. 1).

Загальна кількість авторефератів дисертацій (за виокремленими спеціальностями), які були захищені з 1999 по 2012 рік

\begin{tabular}{|c|c|c|c|c|}
\hline $\begin{array}{c}\text { Рік захисту } \\
\text { дисертації }\end{array}$ & $\begin{array}{c}13.00 .02 \text { (Теорія } \\
\text { і методика } \\
\text { навчання) }\end{array}$ & $\begin{array}{c}13.00 .01 \text { (Загальна } \\
\text { педагогіка та } \\
\text { історія педагогіки) }\end{array}$ & $\begin{array}{c}13.00 .09 \\
\text { (Теорія } \\
\text { навчання) }\end{array}$ & $\begin{array}{c}13.00 .07 \text { (Теорія } \\
\text { і методика } \\
\text { виховання) }\end{array}$ \\
\hline 1999 & - & 9 & - & 1 \\
\hline 2000 & 1 & 1 & 1 & 7 \\
\hline 2001 & - & 4 & 2 & 6 \\
\hline 2002 & 3 & 5 & 5 & 5 \\
\hline 2003 & 2 & 2 & 3 & 4 \\
\hline 2004 & 2 & 2 & 3 & 5 \\
\hline 2005 & 4 & 7 & 5 & 6 \\
\hline 2006 & 1 & 3 & 6 & 9 \\
\hline 2007 & 1 & 6 & 8 & 8 \\
\hline 2008 & 1 & 7 & 6 & 12 \\
\hline 2009 & 2 & 6 & 5 & 4 \\
\hline 2010 & 2 & - & 5 & 14 \\
\hline 2011 & - & - & 1 & 11 \\
\hline 2012 & 1 & - & $\mathbf{5 1}$ & $\mathbf{9 9}$ \\
\hline Всього & $\mathbf{2 0}$ & $\mathbf{5 2}$ & & \\
\hline
\end{tabular}

Табл. 1 констатує, що найбільша кількість робіт виконана 3 питань теорії $\mathrm{i}$ методики в початковій школі (99 авторефератів дисертаційних праць), а найменша - 3 
проблем теорії і методики навчання в початковій школі (20 авторефератів дисертацій з 222).

Таблиия 2

Загальна кількість дисертації, які були захищені з 1999 по 2012 рік

\begin{tabular}{|c|c|}
\hline Рік захисту дисертації & Всього за рік \\
\hline 1999 & 10 \\
\hline 2000 & 10 \\
\hline 2001 & 12 \\
\hline 2002 & 18 \\
\hline 2003 & 11 \\
\hline 2004 & 10 \\
\hline 2005 & 22 \\
\hline 2006 & 15 \\
\hline 2007 & 22 \\
\hline 2008 & 24 \\
\hline 2009 & 26 \\
\hline 2010 & 11 \\
\hline 2011 & 19 \\
\hline 2012 & 13 \\
\hline Всього & $\mathbf{2 2 2}$ \\
\hline & \\
\hline & \\
\hline & \\
\hline
\end{tabular}

Табл. 2 висвітлює різницю й інтенсивність розвитку наукових досліджень $з$ різних аспектів з педагогіки та освіти в початковій школі за роками. Інтенсивність зростання кількості дисертацій за конкретним напрямом науки може слугувати мірою іiі актуальності. Ми бачимо, що пік зростання кількості захищених дисертацій припав на 2009 рік - усього 26 робіт. Після цього йде спад - 11, 19, 13 робіт за рік, який можна розглядати як стабілізацію захисту з 2010 по 2012 рік.

Розглянемо географію захисту дисертацій за 1999-2012 роки (табл.3).

\section{Географія захисту дисертацій за 1999-2012 роки}

Таблиия 3

\begin{tabular}{|c|c|}
\hline Місце захисту дисертації & $\begin{array}{l}\text { Кількість захищених } \\
\text { дисертацій }\end{array}$ \\
\hline м. Київ & 108 \\
\hline \multicolumn{2}{|l|}{ У тому числі: } \\
\hline Київський національний університет культури і мистецтва & 3 \\
\hline Національний педагогічний університет ім. М.П.Драгоманова & 31 \\
\hline Інститут педагогіки, проблем виховання НАПН України & 69 \\
\hline Київський університет ім. Тараса Шевченка & 4 \\
\hline Київський міський педагогічний університет ім. Б. Д. Грінченка & 1 \\
\hline $\begin{array}{c}\text { Одеса (Південноукраїнський державний педагогічний університет ім. } \\
\text { К. Д. Ушинського) }\end{array}$ & 2 \\
\hline $\begin{array}{c}\text { Тернопіль (Тернопільський державний педагогічний університет ім. } \\
\text { В. Гнатюка) }\end{array}$ & 14 \\
\hline Кривий Ріг (Криворізький державний педагогічний університет) & 8 \\
\hline Івано-Франківськ (Прикарпатський університет ім. В. Стефаника) & 7 \\
\hline м. Луганськ & 23 \\
\hline \multicolumn{2}{|l|}{ У тому числі: } \\
\hline Луганський державний педагогічний університет ім. Т. Шевченка & 8 \\
\hline Східноукраїнський національний університет ім. В. Даля & 15 \\
\hline Харків (Харківський державний педагогічний університет ім. & 28 \\
\hline
\end{tabular}




\begin{tabular}{|c|c|}
\hline Місце захисту дисертації & $\begin{array}{l}\text { Кількість захищених } \\
\text { дисертацій }\end{array}$ \\
\hline \multicolumn{2}{|l|}{$\begin{array}{r}\text { Г. С. Сковороди) } \\
\end{array}$} \\
\hline Слов'янськ (Слов'янський державний педагогічний університет) & 1 \\
\hline Житомир (Житомирський державний університет ім. І. Франка) & 5 \\
\hline Дрогобич (Дрогобицький державний педагогічний університет ім. І. Франка) & 1 \\
\hline м. Луцьк & 4 \\
\hline \multicolumn{2}{|l|}{ У тому числі: } \\
\hline Національний педагогічний університет ім. М. П. Драгоманова & 1 \\
\hline Волинський державний університет ім. Л. Українки & 3 \\
\hline Ніжин (Ніжинський державний педагогічний університет ім. М. Гоголя) & 1 \\
\hline м. Херсон & 7 \\
\hline \multicolumn{2}{|l|}{ У тому числі: } \\
\hline Херсонський державний педагогічний університет & 2 \\
\hline Херсонський державний університет & 5 \\
\hline м. Умань & 5 \\
\hline \multicolumn{2}{|l|}{ У тому числі: } \\
\hline Інститут проблем виховання НАПН України & 1 \\
\hline Уманський державний педагогічний університет ім. П. Тичини & 4 \\
\hline $\begin{array}{c}\text { Вінниця (Вінницький державний педагогічний університет ім. } \\
\text { М. Коцюбинського) }\end{array}$ & 7 \\
\hline Запоріжжя (Запорізький національний університет) & 1 \\
\hline Всього & 147 \\
\hline
\end{tabular}

Отже, основне і перше місце захисту дисертаційних праць у рамках розглянутого напряму належить м. Київ - 108 робіт, на другому місці знаходиться м. Харків - 28 робіт. Третє місці за кількістю захищених робіт займає м. Луганськ. -23 роботи. Адже саме ці міста мають наукову школу, сильні педагогічні кадри і професійні колективи в зазначеній галузі.

У досліджених авторефератах дисертацій здебільшого розглянуто питання змісту початкової освіти за рубежем, дидактичне забезпечення процесу навчання в початковій школі, фізичне виховання молодших школярів, інноваційні технології навчання, формування інтелектуальних умінь і психологічні особливості молодших школярів, розвиток позитивної мотивації до навчання, історія розвитку різних аспектів виховання й освіти в початковій школі, професійна діяльність вчителя початкових класів.

Що стосується книжкових видань, то загалом з обраної нами проблематики в загальнодержавній реферативній базі даних «Україніка наукова» представлено 925 рефератів книжкових видань, до складу яких входять підручники, монографії, навчально-методичні посібники для вищих навчальних закладів, навчальні посібники для початкової школи та ін.

Склад рефератів книжкових видань представлений такими авторами, як Н. Бібік, М. Іванчук, М. Іватьо, Н. Ігнатенко, О. Савченко, В. Хорунжий та ін. У цих наукових працях розглянуто основні аспекти розвитку змісту початкової освіти й педагогічної думки (Н. Дем'яненко, М. Свтух, Н. Никало, Б. Ступарик, О. Сухомлинська, М. Яремченко та ін.), що стало помітним внеском у розроблення педагогічної освіти України. Також представлені наукові праці, які розкривають проблеми змісту початкової освіти (М. Скаткін, І. Лернер, В. Раєвський, В. Ледньов та ін.), у яких розглядаються різні аспекти організації початкової освіти; праці українських педагогів С. Васильченка, Г. Васьковича, Б. Грінченка, М. Грінченко, В. Дурдуківського, С. Русової, С. Сірополка, Ю. Тищенка-Сірого, Я. Чепіги, Г. Шерстюка та ін., у яких висвітлюються проблеми національної школи; дослідження провідних учених у галузях теорії та історії педагогіки (М. Вашуленко, Л. Вовк, В. Волошина, С. Гончаренко, 


\section{Н. Гупан, М. Свтух, I. Зайченко, Н. Побірченко, I. Руснак, О. Савченко, М. Стельмахович, Б. Ступарик, О. Сухомлинська, С. Сявавко, М. Ярмаченко) та ін.}

\section{3. ВИСНОВКИ}

Отже, дане дослідження стало одним з аспектів у висвітленні проблеми створення й оприлюднення реферативного ресурсу психолого-педагогічної тематики. Незважаючи на значні досягнення у формуванні галузевого реферативного ресурсу, зрозуміло, що перед бібліотекою залишається ще великий пласт роботи, пов'язаний з потребою збільшення обсягу реферативної продукції з проблем освіти і виховання, що дасть змогу виокремити окрему серію Українського реферативного журналу «Джерело», основою для видання якого слугує «Україніка наукова».

Також аналіз відображення наукових досліджень з проблем освіти й виховання в початковій школі в загальнодержавній реферативній базі даних «Україніка наукова» дасть можливість ВНЗ прогнозувати теми наукових праць для аспірантів і докторантів, тому що на основі аналізу краще видно актуальні напрями наукових досліджень 3 різних аспектів педагогіки й освіти в початковій школі.

Аналіз широко відображає географію міст написання і захисту дисертацій, найбільш і найменш активні ВН3 і наукові центри (табл. 3), що дозволяє визначити кращі вузи й рекомендувати їх співробітникам, науковцям освітянської галузі, аспірантам та докторантам.

\section{СПИСОК ВИКОРИСТАНИХ ДЖЕРЕЛ}

1. Артемов Ю. І. Три етапи інформатизації ДНПБ України ім. В. О. Сухомлинського / Ю. І. Артемов // Історія освітянських бібліотек України : наук. зб. / НАПН України, ДНПБ України ім. В.О. Сухомлинського. - К. : Вирій, 2006. - С. 124-127.

2. Букшина Т. Відображення галузевої науково-реферативної інформації в УРЖ «Джерело»: кооперативна взаємодія освітянських бібліотек / Т. Букшина // Вісник Книжкової палати. - 2012. № $12 .-5 \mathrm{c}$.

3. Коваленко I. Й. Перспективи розвитку галузевого реферативного ресурсу / І. Й. Коваленко, Т. О. Судіна // Сучасний стан та перспективи наукового реферування : матеріали міжнар. семінару-практикуму (29 трав. 2009 р., м. Київ) / Укр. акад. аграр. наук, Держ. наук. с.-г. б-ка УААН. - К. : IAE, 2009. - С. 66-71.

4. Коваленко І. Й. Реферативна діяльність Державної науково-педагогічної бібліотеки України імені В. О. Сухомлинського в умовах модернізації освіти в Україні / І. Коваленко // Наукові праці Національної бібліотеки України ім. В. І. Вернадського. - 2008. - Вип. 22. - С. 46-54.

5. Коваленко І. Й. Реферативне забезпечення педагогічної науки в Україні / І. Й. Коваленко, Т. О. Судіна // Документознавство. Бібліотекознавство. Інформаційна діяльність: проблеми науки, освіти і практики : матеріали V Міжнар. наук.-практ. конф, (20-22 трав. 2008 р., м. Київ) / М-во освіти і науки України, М-во культури і туризму України, Держ. акад. керів. кадрів культури і мистецтва. - К., 2008. - С. 57-59.

6. Мініна Н. М. Система формування реферативної бази даних наукових публікацій України - 10річний досвід / Н. М. Мініна // Реєстрація, зберігання і обробка даних. - 2007. - Т. 9. - № 3. - С. 140-144.

7. Сорока М. Б. Загальнодержавна реферативна база даних «Україніка наукова» як ядро Національної системи реферування / М. Б. Сорока // НТІ. - 2000. - № 3. - С. 58-62.

8. Статистика розподілу публікацій у реферативній базі даних «Україніка наукова», 1998-2013 pp. / Нац. б-ка України ім. В. I. Вернадського. - Режим доступу : http://www.nbuv.gov.ua/db/ref_stat.html. - Назва з екрана.

9. Судіна Т. О. Важливий напрям забезпечення інформаційних потреб освітян / Т. О. Судіна // Пед. пошук.- 2009. - № 2. - С. 56-59. 


\title{
АНАЛИЗ ОТРАЖЕНИЯ НАУЧНЫХ ИССЛЕДОВАНИЙ ПО ПРОБЛЕМАМ ОБРАЗОВАНИЯ И ВОСПИТАНИЯ В НАЧАЛЬНОЙ ШКОЛЕ В ГОСУДАРСТВЕННОЙ РЕФЕРАТИВНОЙ БАЗЕ ДАННЫХ «УКРАИНИКА НАУЧНАЯ»
}

\section{Годз Оксана Владимировна}

канд. филол. наук, научный сотрудник отдела научной реферативной информации Государственная научно-педагогическая библиотека имени В. А. Сухомлинского, г. Киев, Украина oksana_godz@i.ua

\begin{abstract}
Аннотация. Рассмотрены вопросы активизации формирования реферативных ресурсов, по вопросам образования и воспитания в начальной школе. Представлены результаты анализа реферирования научных трудов по вопросам образования и воспитания в начальной школе в государственной реферативной базе данных «Украиника научная». Определены тенденции развития начального образования и воспитания в указанной базе данных. Выявлена реферативная информация активно исследуемых тем в этой сфере и интенсивность их отображения. Поданы результаты мониторинга среди авторефератов диссертаций и книжных изданий по вопросам образования и воспитания в начальной школе, проведенного на основе государственной реферативной базы данных «Украиника научная».
\end{abstract}

Ключевые слова: реферирование; педагогика; начальное образование; общегосударственная реферативная база данных «Украиника научная»; Украинский реферативный журнал «Джерело»; ГНПБ Украины им. В. А. Сухомлинского.

\section{ANALYSIS OF PRESENTATION OF RESEARCHES ON EDUCATION IN PRIMARY SCHOOL IN THE NATIONAL ABSTRACTS DATEBASE «UKRAINIKA SCIENTIFIC»}

\author{
Oksana V. Hodz \\ $\mathrm{PhD}$ (Philology), researcher of the Scientific department of abstracts \\ V. A.Sukhomlinskiy State Scientific Pedagogical Library of Ukraine, Kyiv, Ukraine \\ oksana_godz@i.ua
}

\begin{abstract}
The questions on fostering the formation of abstracts resources on education and training in primary school are considered. There are presented results of analysis summarization of scientific papers on education and training in primary school in the nation-wide database of abstracts "Ukrainika scientific". Tendencies of the development of primary education in the specified database are underlined. It is identified abstracts information of actively studied topics in this area and the intensity of their presentation. There are presented the results of monitoring of theses and book publications on education and training in primary school, conducted on the basis of nation-wide database of abstracts "Ukrainika scientific."
\end{abstract}

Keywords: referencing; education; primary education; nationwide abstract database "Ukrainika scientific"; Ukrainian refereed journal "Djerelo"; V. A.Sukhomlinskiy State Scientific Pedagogical Library of Ukraine.

\section{REFERENCES (TRANSLATED AND TRANSLITERATED)}

1. Artemov Y. I. Three stage of informatization of Ukraine. VASuhomlinskogo / Y. I. Artemov // History educational libraries in Ukraine: Science. Sat / Sciences of Ukraine, Ukraine them. V. A. Sukhomlinsky. -- K., 2006. - P. 124-127 (in Ukrainian).

2. Bukshina T. Industry research - abstract information in URZH "Djerelo": cooperative interaction educational libraries / T. Bukshina // Bulletin of the Book Chamber. - 2012. - № 12. - P. 23-28 (in Ukrainian). 
3. Kovalenko I. Prospects of development of the resource industry refereed / I. Kovalenko, T. A. Suddina // Current status and prospects of scientific referencing: Proceedings of International . workshop 29 herbs. 2009 Kiev / Ukr. Acad. audit. Sciences, State. Sciences . agricultural b Single UAAN. - M. : Institute of Atomic Energy, 2009. - P. 66-71 (in Ukrainian).

4. Kovalenko I. Abstracts activities of the State Scientific Pedagogical Library of Ukraine named V. A. Suhomlinskogo in the modernization of education in Ukraine / I. Kovalenko // Proceedings of the National Library of Ukraine . Vernadsky. - 2008. - Issue. 22. - P. 46-54 (in Ukrainian).

5. Kovalenko I. Review ensuring pedagogical science in Ukraine / I. Kovalenko, T. A. Suddina // Documentation. Librarianship. Information activities: problems of science, education and practice: the V. Intern. scientific and practical . conf. 2-22 herbs. 2008 , Kiev / M of Education and Science of Ukraine, M of Culture and Tourism of Ukraine, State. Acad. pv. Culture and art. - K., 2008. P. 57-59 (in Ukrainian).

6. Minina N. M. Formation system abstracts database of scientific publications of Ukraine - 10-year experience / N. M. Minina // Recording, storage and processing of data. - 2007. - T. 9. - № 3. - P. 140-144 (in Ukrainian).

7. Soroka M. B. Nationwide abstract database "Ukrainika scientific" as the core of the National System of referencing / M. B. Soroka // STI. - 2000. - № 3. - S. 58-62 (in Ukrainian).

8. Statistics distribution of publications in refereed database " Ukrainika scientific", 1998-2013 gg / Nat. the library of the Ukraine. Vernadsky. - Mode of access : http://www.nbuv.gov.ua/db/ref_stat.html. - Title screen (in Ukrainian).

9. Suddina T. A. Important direction to ensure the information needs of teachers / T. A. Suddina // Ped . search. - 2009. - № 2. - P. 56-59 (in Ukrainian). 